

\title{
The Multilingual Environment of Late Antique Egypt: Greek, Latin, Coptic, and Persian Documentation \\ Jean-Luc Fournet
}

\section{To cite this version:}

Jean-Luc Fournet. The Multilingual Environment of Late Antique Egypt: Greek, Latin, Coptic, and Persian Documentation. Roger S. Bagnall. Oxford Handbook of Papyrology, pp.418-451, 2009.

hal-01596956

\section{HAL Id: hal-01596956 \\ https://hal.science/hal-01596956}

Submitted on 28 Sep 2017

HAL is a multi-disciplinary open access archive for the deposit and dissemination of scientific research documents, whether they are published or not. The documents may come from teaching and research institutions in France or abroad, or from public or private research centers.
L'archive ouverte pluridisciplinaire HAL, est destinée au dépôt et à la diffusion de documents scientifiques de niveau recherche, publiés ou non, émanant des établissements d'enseignement et de recherche français ou étrangers, des laboratoires publics ou privés. 
R.S. Bagnall (éd.), The Oxford Handbook of Papyrology, Oxford OUP 2009 p. $418-451$

CHA P T E R 18
MULTILINGUAL

ENVIRONMENT OF

LATE ANTIQUE

EGYPT: GREEK,

LATIN, COPTIC,

AND PERSIAN

DOCUMENTATION one side some isolated cases (Armenian and Syriac), late antiquity witnessed two important changes: (1) the Sassanid occupation, which produced documentation in Pehlevi, and (2) the emergence of a new script intended to record the contemporary vernacular language, Coptic. I limit myself here to these three languagesCoptic, Latin, and Pehlevi, all of which were widely spoken and written in Egypt in the fourth to seventh centuries, analyzing their use and interaction with Greek, which remained the official language and is by far the most abundantly documented. Each of these languages poses in a distinctive way the problem of multilingualism or - for our documentation is only written - of multiliteracy and presents a nuanced picture, ranging from a nearly total and deliberate absence of bilingualism to a deep bilingualism (where the relationship between the languages tends to reverse itself), passing by way of diglossia. ${ }^{x}$

\section{Pehlevi: Languages in Contact WITHOUT INTERACTION}

One language makes a sudden appearance in Egypt's papyrological documentation: Pehlevi, or Middle Persian. The Pehlevi texts of Egypt are limited to the decade of the Sassanian conquest $(619-629),{ }^{2}$ begun by Xusrō (Chosroes) II Parwèz. They total nearly 950-a remarkably large number for such a short timespan.They are written on papyrus, parchment, skin, and linen and come mainly from the Fayyum (figure 18.1). Except for unpublished papyri in Vienna, which vanished after World War II and have only recently been rediscovered, these have been published or republished by Dieter Weber in two volumes of the Corpus Inscriptionum Iranicarum $(C I)$.

The Pehlevi documentation is actually rather disappointing. The texts, almost all fragmentary, are very hard to read because of the extremely cursive and stylized script. The commentary in the editions is also excessively focused on philological matters, making it difficult to draw out its full historical value (Huyse 1995).

All the Pehlevi texts are documentary and secular, above all of a military character (orders, lists of provisions for soldiers, itineraries). Some are connected to commerce, but even there a link with the army exists. Private documents are very rare: a number of private letters (e.g., CII, P. 18, a letter from a Persian to his sister, showing that the Persian population in Egypt was not entirely male but that some families had followed the soldiers) and three sale contracts (Weber 1992a, 501-502).

It is difficult to draw conclusions from these documents about the impact of the Persian conquest on the inhabitants of Egypt and the linguistic relationship between conquerors and conquered. The same is true of the few contemporary
Did the multilingual environment of late antique Egypt change fundamentally compared to earlier periods? The linguistic situation of the fourth to seventh centuries does not at first seem much different from that of the past: As in the Ptolemaic period and under Roman rule, we find the same coexistence of an Egyptian substrate and a Greek-speaking population, plus, since the Roman conquest, a Latin-speaking element with a fairly marginal place. But over the centuries the relationships between these three languages evolved, and, leaving to 


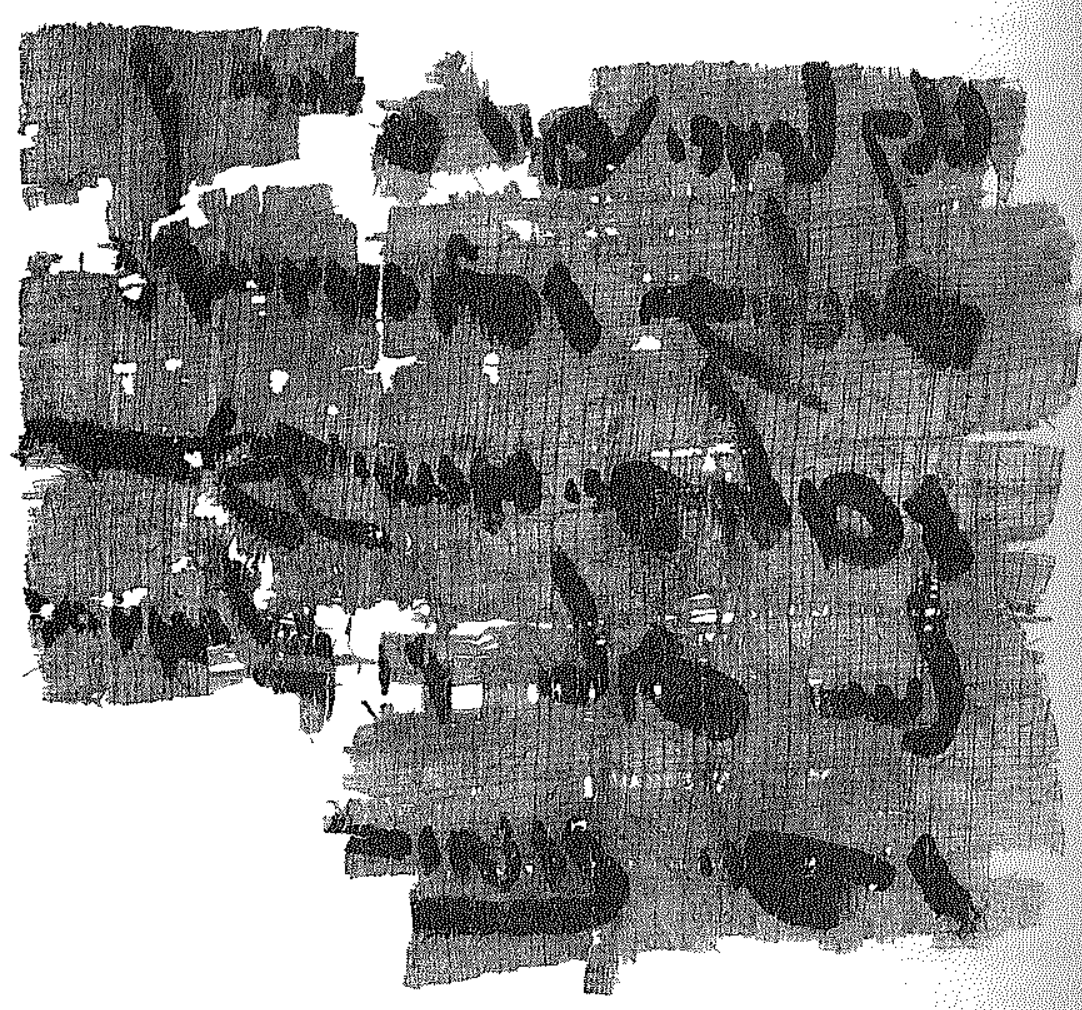

Figure 18.1. An example of a complete Pehlevi document: an order fo delivery (CI, P. 69 = P.Heid. Pahl. 9). Photo courtesy of the Institut fut Papyrologie, University of Heidelberg.

Greek and Coptic texts (Butler and Fraser 1978, xlvi-xlix; MacCoull 1986; AltheimStiehl 1992a; Huyse 1995, 358). The impermeable character of each body of evidence is striking. The Greek and Coptic texts rarely refer to the Persians and do not characterize the nature of relations between them and the Greek-Egyptian population. The Pehlevi texts are focused on military problems (notably on supply), and the local population is nearly absent from them. One good indication is that no Greek, Coptic, or even Latin personal name appears in them, only Persian names except for Abraam (CII, P. 136) and Samuel, a Jewish merchant, perhaps from Elephantine (Weber 1992b, 341; CII, P. 137). Egyptian place names are far more visible (CII, P. 55, 148), but for purely military reasons. In short, there are few connections between the two bodies of documents, with the notable exception of the case of Šahrālānyōzän, a high official who appears in some Greek papyri in the form $\Sigma a \rho a \lambda a \nu \epsilon o \zeta \alpha \nu$ (CI, P. 81; Weber 1991; Sänger 2008).

The papyrological sources give no sign of any bilingualism, however limited, in the population of Egypt. The total absence of bilingual documents is noteworthy, as is that of Pehlevi texts written by Graeco-Egyptians. Certainly there were oral or written contacts. For instance, in P.MoscowCopt. 37-38 the reader Menas says, "I asked the Persians to..."; P.Oxy. LI 3637 says that the recipient had "also had written instructions about this matter from our master the all-praiseworthy Saralaneozan"; CPR IV 48 is a contract for the delivery of linen between the inhabitants of Pousire (Hermopolite nome) and "their master," Perês Kôsrôi (Pèrōz-Xusrō), in which the only instance of an oath "by the safety of the King of Kings" occurs. All these texts show very formal contacts that were carried out through interpreters on the Persian side or by means of networks or institutions already in place and used by the Persians. If any effort at linguistic adaptation was made, it was on the part of the Persians that we must look for it. Thus, the Persians Rasbanas and Remê wrote letters in Greek to the scholasticus Marinus (P.Oxy. LI 3637, XVI 1862-1863; cf. Foss 2002, 170-171).

A few rare points of interference between the two languages, which show that these ten years of conquest, despite everything, did leave various linguistic traces, may nonetheless be noted: The name of the Persian office sälär ("official") passed into Greek in the form $\sigma \epsilon \lambda \lambda \alpha^{\prime} \rho$ ios and appears in several Greek and Coptic documents of this period, particularly in the archive of Theopemptos and Zacharias (Foss 2002). In the reverse direction, the Persians borrowed from Egyptian Greek the words $1 t l$ ' ( $\lambda_{i}^{\prime} \tau \rho a$, "pound") and lagänag ( $\lambda \alpha^{\prime} \gamma v v o s$, a liquid measure).4 These points of contact are, however, limited to borrowings of an institutional nature (title, measures), which can occur even with the most superficial contact.

Several reasons account for this superficiality: indifference, even rejection of the Persians on the part of the Graeco-Egyptians, who did not wish to be friendly with the invader, and most of all the impression that this conquest changed the internal situation in Egypt very little not only because of its short duration but above all because the Persians limited themselves to a military presence and relied for the rest on existing institutions. It is true that our knowledge of this period is still imperfect and would benefit from a fuller study bringing together the Greek, Coptic, and Pehlevi documentation.

\section{Latin: Diglossia with Limited OR IMPERFECT BILINGUALISM}

\section{Latin in Egypt and Imperial Policy}

The situation of Latin in late antique Egypt is paradoxical: Of around 565 papyrological documents partly or entirely in Latin, those of the fourth to seventh century amount to a mere $140 . .^{5}$ To put it another way, the Latin documentation 
of this period is three times less abundant than of the principate (first-third centuries). And yet it is a well-known fact that the reforms of Diocletian and the policies of Constantine brought, along with Romanization at the institutional level, a Latinization of the administration of the eastern provinces, to which Egypt belonged (e.g., Rochette 1997, 116-126). The reforms of Diocletian, by imposing Latin as an official administrative language, undeniably had an effect: Of the 140 papyri in question, about 90 date precisely to the fourth century. The Alexandrian Claudian, as comfortable in Greek as in Latin and official poet at the western court, is one of the best examples of the success of this policy. But the efficacy of this Latinization has long been questioned (Turner 1961; Adams 2003, 635-637, 758). From the end of the fourth century, moreover, imperial policy tended to reaffirm the position of Greek: In 397, judicial decisions were allowed to be rendered in Greek, as well as in Latin; in 439, Theodosius II allowed anyone to make a will in Greek; the prefect Cyrus (439-441) abolished the official use of Latin in the pretorian prefecture of the east; in 450, Latin lost its privileged status at the court of Constantinople; and even Justinian (529-565), who considered Latin his patria lingua, pragmatically issued his Novels in Greek for the eastern provinces and authorized a Greek translation of the legislative collections issued by his government so that the Greek-speaking population might understand them. These



Figure 18.2. Literary papyri in Latin. decisions help to explain the continued dominance of Greek reflected in the Egyptian documents. In any event, although Latin documents are scarce compared to those of the principate (a characteristic in which they are no different from the papyrological documentation as a whole), the high proportion of Latin literary texts for late antiquity is all the more striking (see figure 18.2). This paradox raises questions about the use of Latin in Egypt.

\section{Conditions of the Use of Latin: Superficial Bilingualism or Diglossia}

\section{The Decline of Bilingualism}

Latin-Greek bilingualism is less well attested in the late antique papyri than in those of the Roman period. The reasons for this situation are several: (1) Latin, once obligatory for status documents (like birth certificates) among the very limited body of Roman citizens, was no longer closely tied to Roman citizenship, particularly after that had been granted on all of the subjects of the empire by the Constitutio Antoniniana (212); (2) the growing recruitment of Graeco-Egyptian auxiliaries for the army led to the disappearance of Latin private letters, which are a good indicator of true bilingualism practiced in Latin-speaking circles and are found in quantity at military sites from the principate (e.g., O.Claud., O. Krok., O.Max., O.Fawâkhir). ${ }^{6}$ Nor are there for the fourth to the seventh centuries any archives like those of Claudius Tiberianus and his son, Claudius Terentianus (mainly P.Mich. VIII 467-481, found at Karanis in the Fayyum, 100-120; cf. Adams $2003,593-596$ ), which illustrate the bilingualism of a family of veterans who settled in the Egyptian chôra.

The only bilingual archive from a military milieu is that of Flavius Abinnaeus (Arsinoite, $341-351) .7$ Of the eighty-five texts known, two are in Latin. The first is P. Abinn. 1 (340-342), a petition by Abinnaeus, asking the emperors to confirm his nomination as praefectus alae Quintae Praelectorum, which the dux Aegypti Valacius was refusing him. The second, P.Abinn. 2 (344), is a letter in which Valacius removes Abinnaeus from his position. The use of Latin in these two cases can be explained by the two individuals' knowledge of the language because of their military status. Considering that the rest of the archive is entirely in Greek, however, another explanation is more compelling: Valacius uses Latin to give his letter an official character that might impress Abinnaeus. Similarly, the latter uses Latin to address the empire's highest authorities. Here Latin plays the role of "language of power? "On the evidence of this archive, then, Greek was in regular use as an official, formal language, but Latin was available as a sort of 'super-high' language which could be employed either to make obvious the location of supreme power, or in appeal to a supreme authority" (Adams 2003, 557). ${ }^{8}$ 
Latin as Language and Display of Power

It is striking to observe the disappearance of private letters in Latin. The Latin letters from fourth-to-seventh-century Egypt, as far as we can identify their authors, are almost entirely official letters sent by very high officials: thus, $P . R y t$ IV 623 and Ch.L.A. XIX 687 (Hermopolis, 317-324; figure 18.3), letters of recommendation of rationalis (a high finance official) Vitalis to Delphinius and to Achillius, the governor of Phoenicia, on behalf of Theophanes (and coming from the only Graeco-Latin archive of the period besides that of Abinnaeus; $\mathrm{cf}$, Moscadi 1970); P.Abinn. 2 (cf. above); P.Ryl. IV 609 (Hermopolis, 505), epistula probatoria of the comes rei militaris Thebaici limitis. Latin thus remained the prerogative of the highest officials of the military and civil administrations, on the model of texts coning directly from the chancery of the pretorian prefect ${ }^{9}$ or issued by the emperor (constitutions, edicts, rescripts). ${ }^{10}$

This use of Latin is visible during this period mainly in the bilingual minutes of legal hearings-probably the type of document that most accurately reveals the Greek-Latin "bilingualism" of late antique Egypt, showing the direct influence of imperial policy with regard to Latin, as well as its limits. Despite some earlier examples, it is with Diocletian that such transcripts of hearings before high magistrates, mixing Latin and Greek, develop (figure 18.4)."1 Their particularity lies in the back-and-forth between languages ("code switching"; cf. Adams 2003, 383-390): The formal structure (date, place, formulas introducing interventions) is in Latin: the words of the judge are sometimes in Greek (when he speaks to the defense), sometimes in Latin (when he addresses his officium), while those of the advocates, the accused, or the witnesses are in Greek; the judge's sentence is in either Latin or Greek. "The use of Greek reflects the need for comprehensibility, that of Latin or mixed-language utterance, the exclusion of some hearers for a moment from the proceedings, and a desire on the part of the officials to present themselves symbolically as representatives of Rome and as an exclusive group" (Adams 2003,386).

One might ask whether the Latin in these texts was not a fictitious representation of what actually happened. Such doubts would be exaggerated for the fourth century. But a comparison between the use of languages in the transcripts of the fourth century and those of the fifth and sixth (Rochette 1997, 119-20) shows that the colloquy and sentence were only in Greek from the fifth century on. The increasingly local recruitment of high officials may explain the gradual loss of adequate competence in Latin. In any case, however, the formal framework remains in Latin, showing that the language played, even if artificially, the role of a language of power. In other documents, only the date or a validation formula (e.g., legi, proponatur) is enough. Rather than bilingualism, we must speak of diglossia, even if superficial.

This required use of Latin, moreover, increasingly stereotyped and distant from natural usage, betrays itself in the Latin documents by various symptoms like the faulty insertion of Greek letters, a failure to respect the rules of Latin spelling, and morphological confusions. ${ }^{12}$

\section{Latin as a Language of Law}

The use of Latin in transcripts of trials is also tied to the fact that Latin was the language par excellence of law. Roman law, the only valid system at this period, was obviously expressed in Latin, and after the Antonine Constitution many officials needed to know it. Diocletian certainly encouraged the study of law, granting privileges to officials who studied it and creating new professorships of Latin in the east. Alexandria became an important center for the study of legal Latin, competing with or complementing the famous law school of Beirut. This spread

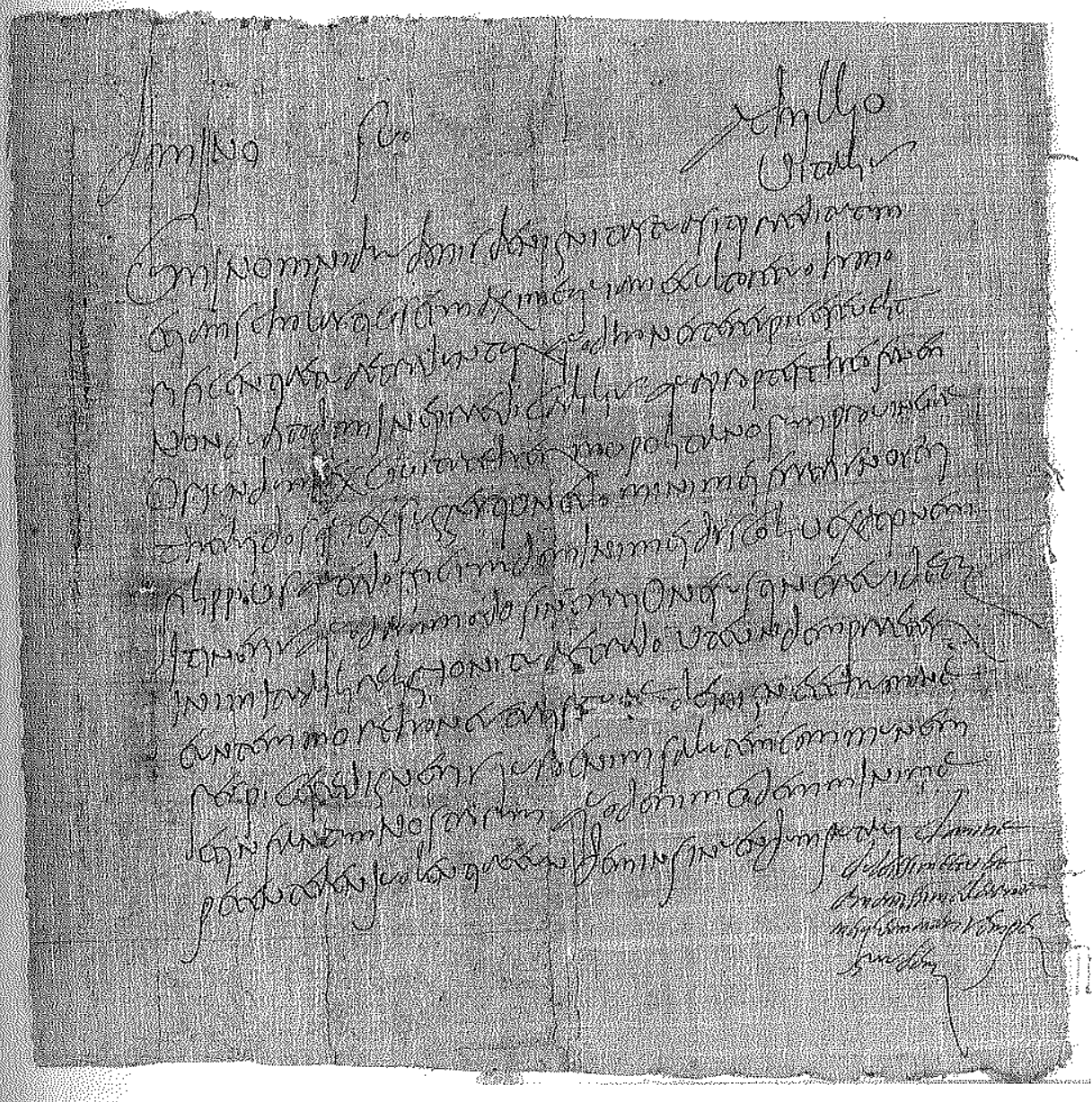

Figure 18.3. Letter of recommendation from the rationalis Vitalis to the governor of Phoenicia on hehalf of Theophanes of Hermopolis (Ch.L.A. XIX 687, 317-324 = P.Stras. (ivv. Li). Photo and collection of the Bibliothèque Nationale et Universitaire de Strasbourg. 

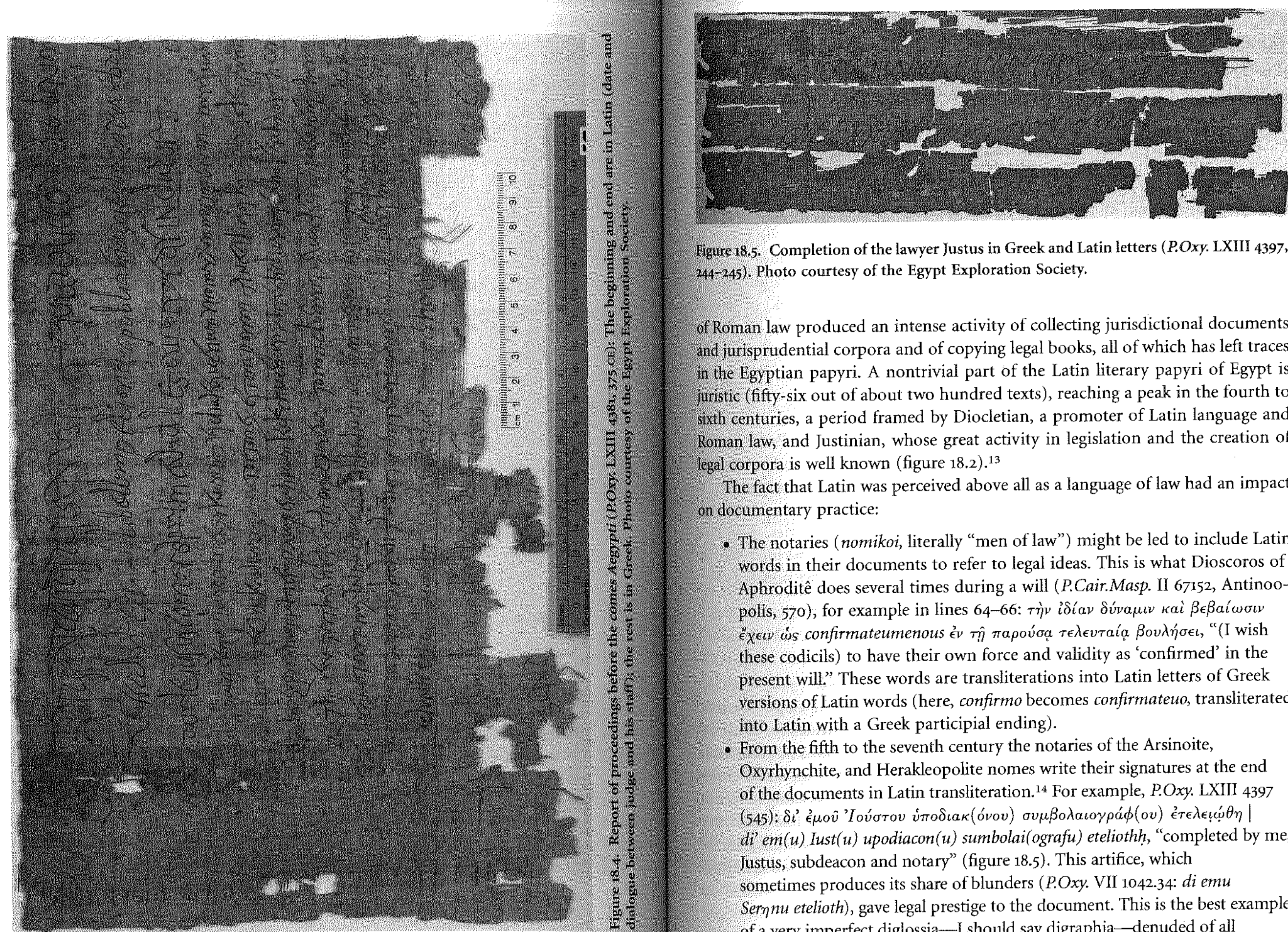

Figure 18.5. Completion of the lawyer Justus in Greek and Latin letters (P.Oxy. LXIII 4397, 244-245). Photo courtesy of the Egypt Exploration Society.

of Roman law produced an intense activity of collecting jurisdictional documents and jurisprudential corpora and of copying legal books, all of which has left traces in the Egyptian papyri. A nontrivial part of the Latin literary papyri of Egypt is juristic (fifty-six out of about two hundred texts), reaching a peak in the fourth to sixth centuries, a period framed by Diocletian, a promoter of Latin language and Roman law, and Justinian, whose great activity in legislation and the creation of legal corpora is well known (figure 18.2). ${ }^{13}$

The fact that Latin was perceived above all as a language of law had an impact on documentary practice:

- The notaries (nomikoi, literally "men of law") might be led to include Latin words in their documents to refer to legal ideas. This is what Dioscoros of Aphroditê does several times during a will (P.Cair.Masp. II 67152, Antinoo-



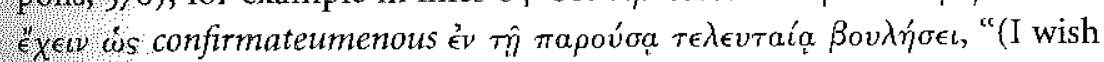
these codicils) to have their own force and validity as 'confirmed' in the present will:" These words are transliterations into Latin letters of Greek versions of Latin words (here, confirmo becomes confirmateuo, transliterated into Latin with a Greek participial ending).

- From the fifth to the seventh century the notaries of the Arsinoite, Oxyrhynchite, and Herakleopolite nomes write their signatures at the end of the documents in Latin transliteration. ${ }^{14}$ For example, P.Oxy. LXIII 4397

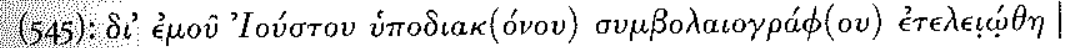
di em $(u)$ Iust ( $u$ ) upodiacon ( $u$ ) sumbolai (ografu) eteliothh, "completed by me, Justus, subdeacon and notary" (figure 18.5). This artifice, which sometimes produces its share of blunders (P.Oxy. VII 1042.34: di emu Sernnu etelioth), gave legal prestige to the document. This is the best example of a very imperfect diglossia - I should say digraphia - denuded of all bilingualism. 
Latin Literary Papyri: The Needs of a New Class

The development of Latin as a language of power and law, however marginal or superficial, led to the emergence of a new class of civil and military officials and of lawyers (scholastikoi) who had to acquire at least a rudimentary knowledge of Latin. This learning process is well documented by the Latin literary papyri found in Egypt. The graph of these papyri is highly significant when compared to that of Greek literary papyri, which reaches its peak in the second century; it rises abruptly in the fourth century and reaches a peak in the fifth before falling again (figure 18.2). The Latin papyri attest various phases of learning, ranging from elementary teaching to a higher level (Rochette 1997, 165-210; Adams 2003, 623-630): (1) Latin alphabets with equivalents of Greek letters, sometimes with the names of Latin letters in Greek; (2) writing exercises; (3) Latin or Graeco-Latin grammars; (4) Graeco-Latin glossaries (where Latin is often transliterated into Greek) of several types: ${ }^{15}$ alphabetic or thematic glossaries or glossaries of Latin authors (Rochette 1990, 1996; C.Gloss.Biling. II pp. 5-8); (5) conversation manuals; (6) collections of model letters (just one case, from the third-fourth century, P.Bon, 5 , which gives letters with a strongly legal character as examples); (7) Latin authors (Mertens 1987), above all Cicero and Vergil but also Juvenal, Livy, Lucan, Sallust, Seneca, Terence, anonymous works like the Montserrat Alcestis (Mertens-Pack ${ }^{3}$ 2998.1, fourth century), or the Psalmus Responsorius in the same codex (van Haelst 1210) and legal authors (e.g., Gaius, Papinianus, Ulpian, Codex Theodosianus).

Various indications, like transliteration into Greek (Kramer 1984, 1378-1379: Rochette 1999) and the use of administrative vocabulary in the glossaries, show that these papyri were composed mainly for Greek speakers, who were less interested in the glories of Roman culture than in the necessity-more and more pressing from Diocletian on-to learn Latin quickly for practical reasons.

\section{Latin in Christian Milieus}

The Latin-Greek-Coptic conversation manual (Mertens-Pack ${ }^{3}$ 3009=PRain. Unterricht kopt. 270, C.Gloss.Biling. I 15, sixth century), given its Coptic element and the religious coloration of its lexicon, seems to have been intended for Christian (perhaps monastic) circles. It poses the problem of the connections between Latin and Christian milieus (Cavenaile 1987). A number of Latinized monastic circles existed in Egypt, but these were very marginal: It was for Latin-speaking monks of the Pachomian congregation that Jerome translated Pachomius's rule into Latin (404). Apollô directed a community near Hermopolis where several monks, we are told, were "versed in Greek, Latin, and Egyptian" (Historia Monachorum in Aegypto 8.62). More interesting is the presence of Latin in the Montserrat codex mentioned earlier, part no doubt of an ancient collection of Christian books in Greek and Coptic from the region of Nag Hammadi, to which a Greek-Latin lexicon of the Pauline epistles also belonged (Wouters 1988). This library, the setting of which is still controversial, may have belonged to a religious community (perhaps sectarian) of Upper Egypt (Agosti 2002, 80-87), and these texts demonstrate that its members needed instruction in Latin, as well as Greek and Coptic. Similarly, among the Manichaeans of Kellis, the need to learn Latin was felt around the same time (P.Kellis V C. 20.24-26: "The Great Teacher let him travel with him, so that he might learn Latin'), perhaps for missionary purposes.

Other Latin papyri from a Christian setting are rare and hard to interpret because we know little about their precise context: P.Lond. V 1792 (fifth-sixth century), a Latin letter addressed by an epitropos to an ecclesiastic, and the curious cluster of Greek letters introduced by a Latin sentence of biblical inspiration, with Latin docket (P.Oxy. XVIII 2193-2194 and P.Köln IV 200, fifth-sixth century). Other than those already mentioned, Christian literary papyri in Latin are the products of schools. PSI XIII 1306 (fourth-fifth century), Ephesians in Latin and Greek; P.Rain. Unterricht 184 (sixth-seventh century; with regard to the date, cf. P.Thomas, pp. 19-23), Latin Lord's Prayer with transliteration into Greek.

The data are scant and difficult to use. Despite everything, Latin remained marginal: Greek was the official language of the church, Coptic its natural language and that more customary in monastic milieus.

\section{Consequences of Latino-Greek Bilingualism or Diglossia}

It is not always easy to distinguish between the results of Romanization and those of Latinization. The most obvious result of the latter is the penetration of numerous Latin words into the Greek of Egypt, a phenomenon visible already under the principate but limited essentially to military milieus and certain semantic fields (cf. Ghiretti 1996) and much more evident from Diocletian on. These words, collected earlier by Daris (1991), are now the object of a specialized dictionary based on Greek and Coptic sources, Lex.Lat.Lehnw., which will provide a solid base for a complete study of the impact of Latin on the Greek of Egypt. For the moment, we may simply recall that Latin words were obviously introduced in the domain of civil and military institutions and of taxation as a result of imperial reforms (sometimes going so far as to duplicate Greek words, like $\delta \eta \phi \eta^{\prime} v \omega \omega \rho<$ defensor, next to é k $\delta i k o s)$. More revealing are numerous Latin words that concern artisanry (names of trades and products, especially textiles and foodstuffs). The impact of Latinization is also visible in the degree of adaptation by the borrowing language. We see, indeed, many hybrid words (Daris 1991, introduction): verbs with Greek suffixes ( $\dot{\alpha} \mu \beta \iota \tau \epsilon \dot{v} \omega<$ ambio; ${ }^{\epsilon} \xi \pi \epsilon \lambda \lambda \epsilon \dot{v} \omega<$ expello), sometimes without any Latin

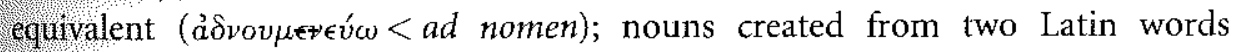



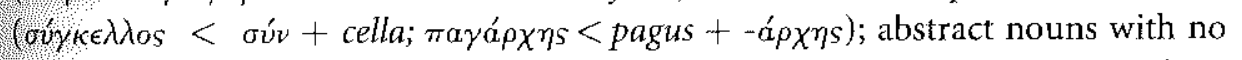
Latin equivalent (' $\epsilon^{\prime} \xi a \kappa \tau o \rho i ́ a<$ exactor; $\rho \iota \pi a \rho i a<$ riparius). Such formations show 
how perfectly Latin words were integrated into the borrowing language. The influence of Latin is also apparent at the level of handwriting, especially in the development of the so-called Graeco-Latin graphic koinê (see chapter 5). Finally, as far as bibliology is concerned, Roman juristic practice, which privileged the codex, was certainly one of the influences (along with Christian books) in the eventual triumph of the codex over the bookroll and its adoption not only for accounting and recordkeeping but also for literary authors (Gascou 2000, 289-291). Greek paideia, so resistant to Latin influence, finally bowed before Roman pragmatism, but here we move into the complex domain of Romanization and leave the realm of language for the broader world of culture.

\section{Coptic: Diglossia With ReAL BILINGUALISM}

The relationship of Greek and Coptic is richer, better documented, and more complex. The population of late antique Egypt mostly spoke its vernacular language, Coptic, or more exactly "Egyptian," as the papyri say, hut in some circumstances it had to use Greek, the language common to the entire east. The problem, more fundamentally, is one of the relationship of a population with its administration and elites-relationships in which the phenomena of multilingualism and diglossia are most clearly observable. There is much in this area we still do not know, above all because Coptic papyrology has advanced less rapidly than Greek. Recent discoveries (Kellis) are in the process of shedding new light, but the moment for a full synthesis has not yet arrived. In short, Coptic papyrology is a domain in the midst of change and expansion (Clackson 2004). ${ }^{16}$

\section{The Birth of Coptic}

The first three centuries of Roman domination witnessed the decline of the vernacular scripts: The hieroglyphs, no longer used except as an artificial script in monumental inscriptions, disappear after 393/394 (Philae); hieratic, also tied to temple culture, starts becoming incomprehensible even to priests starting in the second century, as the Onomasticon of Tebtynis shows, with its marginal glosses in demotic and Old Coptic (Osing 1998, papyrus I). Starting in the middle of the first century, even demotic, the only script in current use to represent the spoken Egyptian language, declines along with the temples where it was taught, and it vanishes almost completely in the third century, even though it is attested as late as a graffito at Philae in 452/453 (Bagnall 1993, 237; Lewis 1993; Fournet 2003a, 429430). The Egyptians thus found themselves without a script for communication among themselves and were obliged, if they could, to use Greek-a point important for the decline in the quality of written Greek, visible in many papyri of the second to the fourth centuries.

Furthermore, it was to the convenient, alphabetic Greek that they turned to try to create a new script. Apart from some transliterations of names, it is only in the first-second century that the first attempts at creating a coherent graphic system are found, one that used the Greek alphabet augmented by some demotic signs denoting phonemes absent in Greek: This is what is called Old Coptic (Quagebeur 1982, modified by Bagnall 2005), born in a pagan milieu intent on preserving traditional learning and allowing the recording of texts tied to cult practices such as magic and astrology. The school ostraca of the temple of Narmouthis (Fayyum), which date to the second to third century, in which hieratic words are transliterated into Old Coptic (O.Narm.Dem. II 34-41), offer a good example of the context in which these experiments in Old Coptic were conducted (figure 18.6).

Among the varied experiments in Old Coptic, it is probably in the third century that one took hold, was diffused by pathways still obscure to us, and led to the birth of Coptic properly speaking (Bagnall 2005, 18). This, unlike Old Coptic, was certainly a deliberate creation that resulted from Christian initiative in well-off, Greek-speaking Egyptian circles-hence the large quantity of Greek words in Coptic (about 20 percent), not only concrete ones but also auxiliary words like conjunctions and prepositions. ${ }^{17}$ Coptic is thus the offspring of Greek-Egyptian bilingualism, designed above all for the translation of the scriptures into a vernacwlar tongue - a need evident already in the third century in the Coptic glosses to the Greek text of Isaiah in P.Chester Beatty VII or the minor prophets in a codex in the Freer Collection (van Haelst 293, 284). In the following century, Coptic expanded dramatically not only as a literary medium but also for ordinary use, still in Christian circles. The Egyptian population, which became mainly Christian in this period, had from this point on its own means of writing, which allowed it to communicate in its own language. The expansion of Coptic had consequences for Greek: With those only uneasily bilingual now able to communicate in Coptic, the quality of the language in Greek letters recovers something of its higher level seen in the Hellenistic period.

Despite the rapidity of the spread of Coptic and the homogeneity of its users, from a linguistic standpoint it was highly diverse: It was made up of several dialects identifiable in their phonological and graphic variation. These are mainly, from north to south, Bohairic (B), Fayyumic (F), Mesokemic (M), Akhmimic (A), subAkhmimic or Lykopolitan ( $\mathrm{A}^{2}$ or L), and Sahidic (S). ${ }^{18}$ Sahidic ("southern dialect") was the standard Coptic literary dialect until its displacement by Bohairic ("northein dialect") in the tenth century, probably because of the settling of the Coptic patriarchate in Wadi Natrun (west delta). 




Figure 18.6. A school exercise in hieratic writing with translation in Old Coptic (O.Narm.Dem. II 38, second-third century $\mathrm{CE})$, facsimile. Courtesy of Paolo Gallo.

\section{Coptic versus Greek}

Characterizing the relationship between the use of Coptic and the use of Greek and, on the basis of that, describing the Egyptian-speaking community are difficult problems that have been approached through various methods.

\section{A Complex Problem: Inadequate Criteria}

(1) ETHNICITY

This is difficult to perceive. Legal categories are useless because the terms "Egyptian" and "Greek," as the Romans used them, did not correspond to any ethnic realities. only to legal and fiscal distinctions (thus, the Greeks of the chorra were classified as "Egyptians"); moreover, these were obsolete by late antiquity. Only with the coming of the Arabs would a new term arise, "Copt" (a deformation of the Greek word Aigyptios, "Egyptian"), which designated the Egyptians-all Christians - in opposition to the Muslim Arabs.
Nor are naming practices able to reveal ethnicity from the fourth century on. The onomastic repertory was Christianized, thereby partly erasing the differences between Greek and Egyptian names. We see, moreover, particularly in the fourth century, a fashion for certain Greek names even among the Copts; and, finally, some Graeco-Egyptian names (and even Latin ones) are of indeterminate character. The names of the authors of fourth-century Coptic letters found at Kellis (P.Kell. V) are sufficient proof: Egyptian names, to be sure (Psemnouthes, That, Shamoun); but also Graeco-Egyptian (Horion), Christian (Matthaios, Makarios), Greek (Lysimachos), and Latin (Valens) names.

In a class by itself was Alexandria, a profoundly Greek city that had no very visible Egyptian-speaking population, as the absence of Coptic inscriptions and graffiti shows.

\section{(2) RELIGION}

Athough this is more solid, it is complicated to handle. Pagan (or paganizing) Hellenism has often been set up against a Coptic Christian culture. This distinction, always too schematic, becomes unworkable after Christianity becomes the state religion under Constantine. Another schematic opposition, between antiChalcedonian Christians who spoke Coptic and Chalcedonian Christians who spoke Greek, ${ }^{19}$ depends on a nationalistic vision that has been strongly criticized of late (Wipszycka 1992, esp. 122-125). This opposition is all the more futile in that the Chalcedonian/anti-Chalcedonian split is almost entirely absent from the papyrdogical documentation and does not seem to have been a criterion of linguistic differentiation. The language of the church of Egypt remained Greek as long as possible. It was the liturgical language and the language of communication between the patriarch of Alexandria and his bishops. The festal letters, veritable treatises with doctrinal and disciplinary content sent by the patriarch to the bishops of Egypt each year to announce the date of Easter, were still written in Greek well after the Arab conquest ( $B K T$ VI $5=$ van Haelst 621 , from 713 or 719 ). Greek was the language of Christian public space, as, for example, in the monumental inscriptions in Egyptian churches (see the inscription of the Mu'allaqa, the "Hanging Church" from 735; Fournet 1993).

This inadequate dichotomy has given way to a more legitimate opposition: Greek was the language of the church, but Coptic was spoken by most of the monks. Monks and anchorites could get by without Greek and use the maternal language of the majority, whether by deliberate rejection of Greek, by indifference toward the Greek paideia so ubiquitous in the world, or by cutting themselves off from public life, where Greek remained indispensable. In fact, the majority of Coptic papyri from the fourth to the seventh centuries come from monastic settings or from sectarian religious communities like the Gnostics or Manichaeans. But Egyptian monasticism was more diverse than is often thought: Besides the Latin speakers mentioned earlier, it included a Greek or Greek-speaking component (Wipszycka 
1992, 115-116) and even to some extent encouraged Greek, which was necessary for managing the monasteries' economic activities. Moreover, in early Egyptian monasticism, those monks and anchorites, who acted as intermediaries between the population and the authorities, needed Greek. We see this from the bilingual fourth century archives of the Melitian monastery of Hathor and of Apa Johannes (mentioned later), which contradict the ideological vision transmitted by hagiographic literature (van Minnen 1994).

At the same time, it was quite possible for important church positions to be occupied by Copts who did not speak Greek (Wipszycka 1992, 110). Kalosiris, bishop of Arsinoe, needed an interpreter at the Council of Ephesos (ACO II///i, p. 185, 9o); the bishops Abraham of Hermonthis and Pisenthios of Coptos (sixth seventh century) did not know Greek.

This connection between Coptic and the monks (supposedly poor and reject ing the city) has led scholars to propose a third criterion.

\section{(3) SOCIAL AND ECONOMIC STATUS}

Urban communities, because they were more affluent and cultivated, would on this view have spoken mainly Greek, while village populations (less rich, uneducated) spoke Coptic. This schematization is partly valid (especially for the urban elites involved in municipal duties), but the use of the two languages was actually less simply divided. Centuries of cohabitation had led Greeks to learn Egyptian, particularly in the course of managing agricultural estates-a point on which the papyri do not inform us adequately. In return, some categories of villagers needed Greek in order to manage their businesses and carry on village duties, as well as in relations with the pagarch and the metropolis. A kind of natural bilingualism thus developed. In the fourth century, the villagers of Kellis, even if they have Egyptian names, write both Greek and Coptic. In the sixth century, the archives of the village of Aphrodite are almost entirely in Greek, and one of its inhabitants, Dioscoros, not only was capable of drawing up Greek legal documents as a notary in the capital of his province the Thebaid, but could also write poems in Greek. In short, this criterion also gives only an imperfect account of spoken bilingualism and simultaneousty fails to explain the distribution of the written documentation between Greek and Coptic.

The best explanation of the evidence is that the two languages were complementary, depending on the context of usage; in other words, there was a functional link between language and type of written document, which evolved over time Bilingualism combines with a clear diglossia, the contours of which gradually change

\section{The Complementarity of the Two Languages by Genre}

The number of Coptic documents follows an upward curve (figure 18.7), almost the reverse of that of Greek documents. ${ }^{20}$ These two curves clearly illustrate that the conditions of use and complementarity of Greek and Coptic evolved between

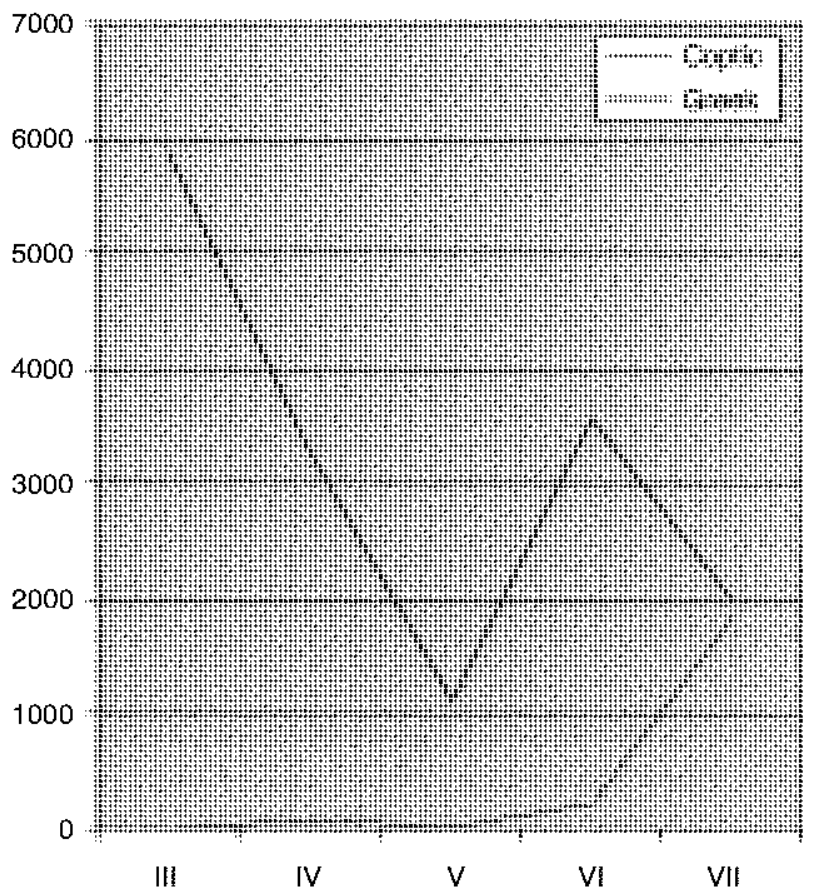

Figure 18.7. Quantitative comparison of Greek and Coptic documents.

the fourth and seventh centuries-to the benefit of Coptic, which would replace Greek in its major domain, legal documents, after the Arab conquest, which marked the end of Byzantine rule in Egypt (Richter 2002, 16-27). Three phases can be distinguished, which we will treat by looking at the bilingual archives of each period: these demonstrate the relationship between Greek and Coptic and its evolution, as shown in figure 18.8, which classes the Coptic documents according to three types (letters, accounts/lists, others). ${ }^{21}$

\section{(1) FOURTH CENTURY TO ABOUT 57O: THE DEVELOPMENT OF} COPTIC

For this period, we have two Graeco-Coptic archives:

- The archives of the Melitian monastery of Hathor (Kynopolite nome), made up of that of its abbot Apa Paieous $(334-340)^{22}$ and that of one of his successors, Nepheros (350-360). ${ }^{23}$ Paieous, with his Egyptian name, knew both Greek and Coptic; he signed in Greek on a contract (P.Lond. VI 1913.18), giving his name a Hellenized form, Pageus; he also received numerous letters in Greek and at the same time wrote (?) and received letters in Coptic (P.Lond. VI 1920-1922). The same is true of Nepheros. Coptic is used only for letters in these archives, while other documents (contracts, receipts, 


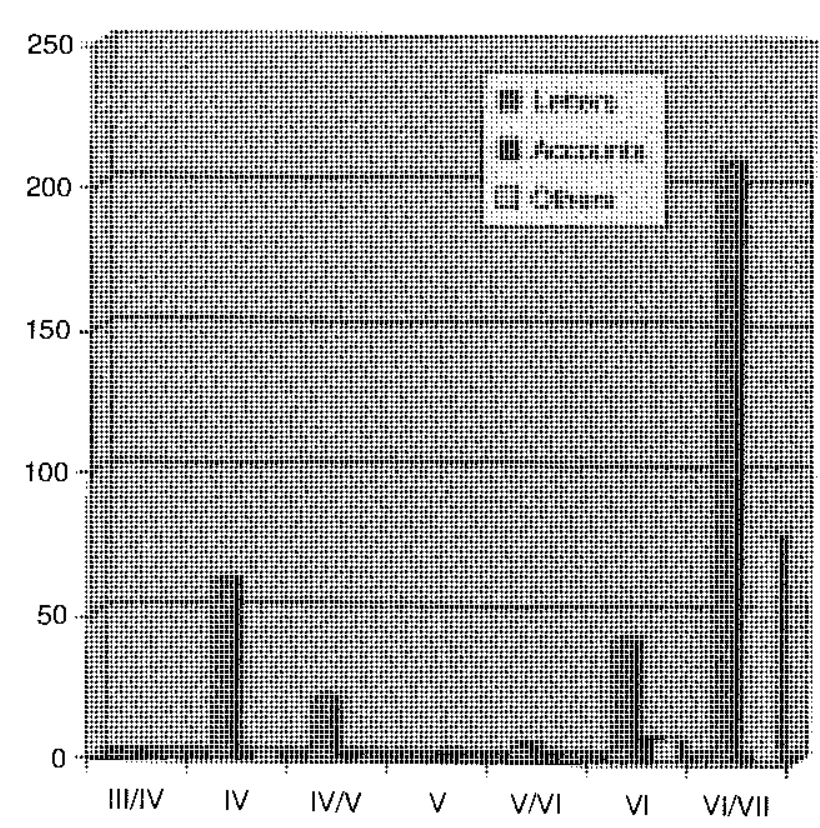

Figure 18.8. The Coptic documents from the beginning up to the Arab conquest.

accounts) are in Greek. It is worth noting also that the three Coptic letters in the dossier of Paieous concern very down-to-earth subjects (making clothes sending provisions), in contrast to some of the Greek letters, which deal with important subjects like the relations between the Melitian congregation and the bishop of Alexandria (P.Lond. VI 1914). Moreover, the editor of P.Lond. VI 1914 regarded the writer as a Copt (because of the errors he made); as a result, the choice of Greek would have been linked to the nature and importance of this letter, a kind of official report.

- The archive of the anchorite Apa Johannes (Lykopolis, ca. 375-40o).24 This dossier is made up of letters in Greek and in Coptic, addressed by monks, churchmen, soldiers, officials, and private individuals to Apa Johannes, who is identified with the famous John of Lykopolis, a "holy man" known from the literary sources (Zuckerman 1995, 188-194).25 These persons ask John to pray for them or to intercede in their favor with the authorities. It is difficult to assess the reasons for the choice of language, particularly when the senders do not give their identity. Some of the authors of Coptic letters, however, are certainly monks (P.Ryl.Copt. 268, 269,271,313). Even this, however, is not so simple: One of supplicants, Psoïs, writes to Apa Johannes in Greek, even though the poor quality of his Greek shows that he was a Coptic-speaking Egyptian (P.Herm. 7). It is thus all the more surprising to find Psoïs writing in Greek to a Copt who is said not to have known Greek. We have in fact a letter by
Apa Johannes himself, written in Greek, but only its signature is in his own hand, and that is in Coptic (P.Amh. II 145; figure 18.9). To put it another way, Apa Johannes must not have known Greek (information confirmed by Palladius) and, in order to deal with the numerous requests he received, used a "secretariat," which translated those in Greek for him and drew up at his request letters that he needed to send in Greek. The letter of Psoïs shows that a Copt could feel himself obliged to write in Greek to another Copt.

To these two archives we may add, besides the papyri from the Nag Hammadi cartonnage, those from Kellis (Dakhla Oasis), which, although they do not form an archive properly speaking, are of the greatest interest:

- The texts from Kellis (ca. 350-37o) come from a Manichaean circle. ${ }^{26}$ Apart from a number of accounts, the Coptic texts are private letters, while the Greek papyri include, besides private and business letters, petitions, receipts, and a variety of official and legal documents (e.g., prefectural edict, loans, sales, manumission). Apart from this clear partition, one is struck by the perfect bilingualism of some of the main figures. Thus, Tithoes writes a Coptic letter to his son, Samoun (P.Kell. V C. 12), while the latter writes a letter in Greek to his father (P.Kell I 12). Moreover, Tithoes and Samoun receive letters in Greek from Ammonios (P.Kell. I 10 and 11). A woman named That goes from Coptic to Greek within a single letter without an obvious reason (P.Kell. V C. 43). The bilingual character of this community is well summed up in Makarios's recommendation to his "son," Matheos: "Study [your] psalms, whether Greek or Coptic" (P.Kell. V C. 19.13-14).

These three groups very clearly show a division between private documents written in Coptic and legal documents written exclusively in Greek. Apart from some private accounts, Coptic is reserved for private letters. Nonetheless, these remain strongly marked by Greek in that they borrow structure and formulary from Greek letters; in some cases, the address (prescript), the final salutation, and the endorsement are written in Greek. All of this presents a picture of a population more bilingual than one might have expected, one that, except the particular case of legal documents, moved from one language to the other according to criteria that are not always evident to us and are not based on belonging to a monastic community or on not knowing Greek. The case of Psoïs plainly shows that, in the fourth century, a permeability between the two languages continued to exist, made possible by widespread bilingualism even if sometimes imperfect. The nationalist conception of the use of languages is clearly untenable.

(2) CIRCA 570-642: A PERIOD OF TRANSITION

This was a hinge period, during which Coptic began to be used, rather timidly, for legal documents (included in "Others" in figure 18.8). Four archives date to this period and illustrate this phenomenon well: 


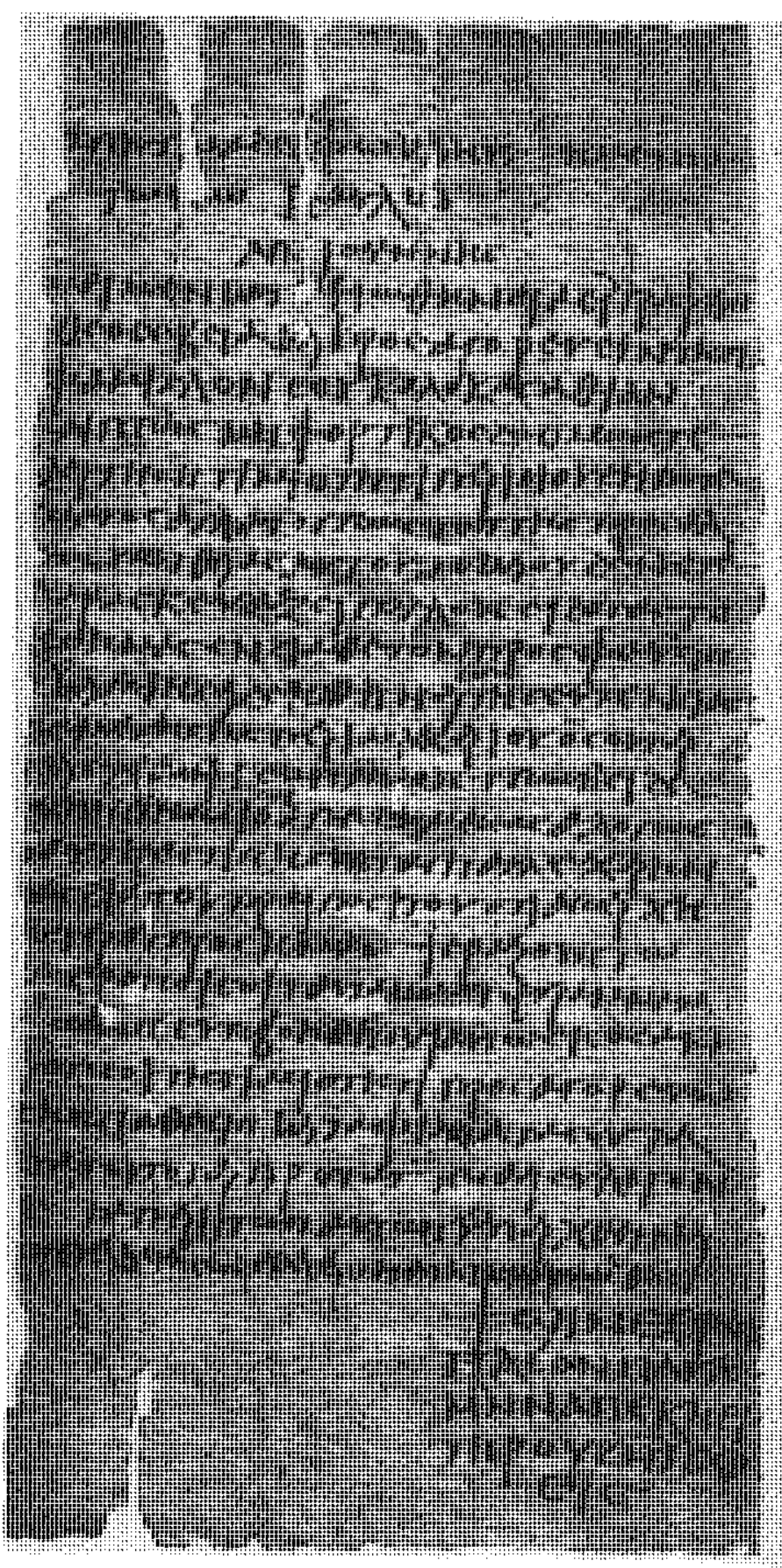

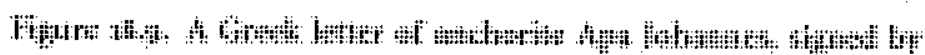

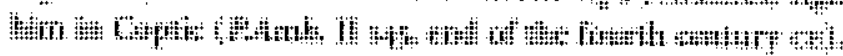

The atitut tioscoros of Aphrodite $(506-585)^{27}$ is the largest group of

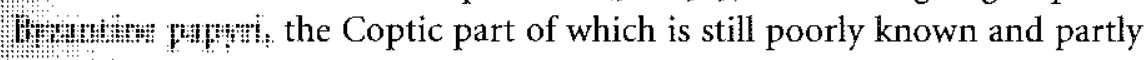

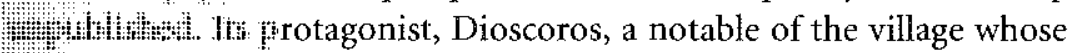

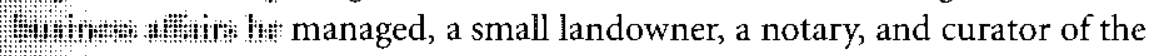
Intmenterthented by his father, knew both Coptic (his native language)



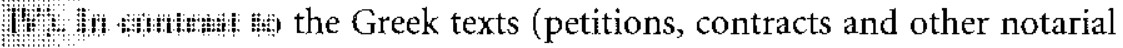

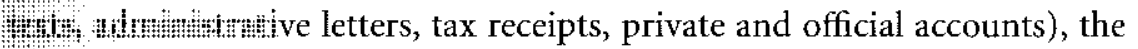
- untrat the toptic texts are letters, either private or concerned with his Wint thementery (MacCoull 1991, 1992, 1993). But we also find here, for the it a 1 imen: in tuptic, texts of another sort: two arbitrations drawn up by

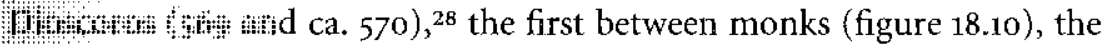



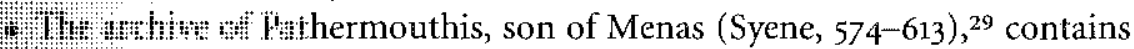



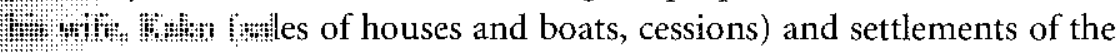
(t: pure that these provoked among members of the family. The few Coptic

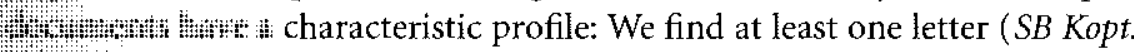

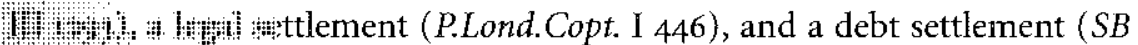
I.t. III Iytut. Woreover, the only documents of the archive in which Kako




I trim tontwill in Greek (Clackson 2004, 29).

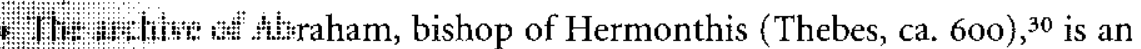

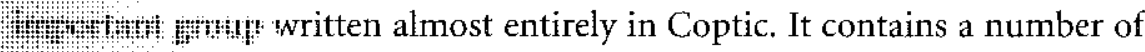
un on tomeming: Abraham's pastoral activity. More original is, for the first

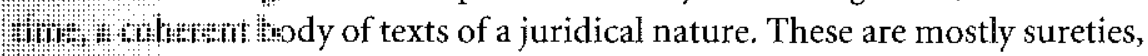

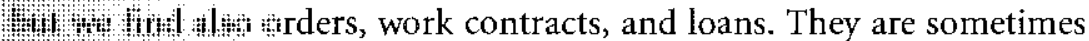



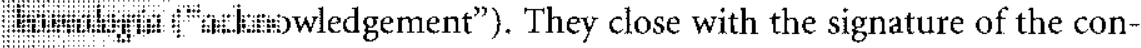
(1. in in party tritl sometimes with a witness (using the Greek verb stoikhei, 1 Inrent the must underline the fact that these apparently legal texts menterminatesiastical context. On the other hand, while he is abbot of



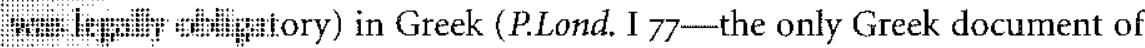

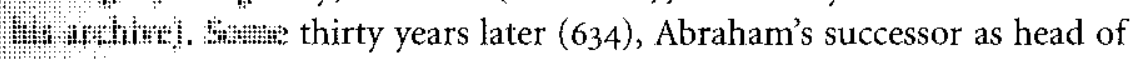
Itte entret mentemry, Apa Victor, made his will in Coptic (P.KRU 77). This

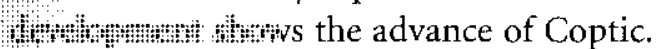

4 The antull intature of Pachymios, purple-seller (Panopolis, 592-616), ${ }^{31}$ tarimmen vartases types of contracts in Greek (house sales, property division,



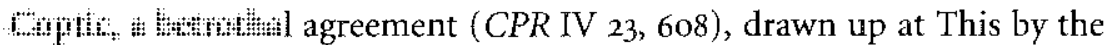


monasteries, which attracted people of all ages, varying backgrounds, and unequal literacy, have provided many examples of this double education; thus, in the Theban region, that of Phoibammon (Cribiore 1996, no. 19) or that of Epiphanius (P.Mon.Epiph. II 611-620).

To these we must add the lexica, glossaries, and Graeco-Coptic conversation manuals, notably P.Rain.Unterricht. kopt. 270 ( $=$ C.Gloss.Biling. I 15), a Latin-Greek Coptic manual of the sixth century; the Greek-Coptic lexicon of Dioscoros of Aphroditê (P.Rain.Unterricht. kopt. 256, sixth century); and an Old Testament glossary (P.Rain.Unterricht. kopt. 257a, third-fourth centuries).

\section{Fluent Literacy}

Besides the bilingual letter writers of Kellis, I have already mentioned the bilingual notaries (e.g., Dioscoros of Aphroditê; Paul of This). These notaries were proficient in not merely two languages but two scripts as well: They were in effect capable of switching from one language to the other, fluently employing the writing style appropriate to each (from the fifth-sixth century on, Greek was more cursive than Coptic) (figure 18.12). In addition, when they drew up a contract in Greek they were aware of the problems of bilingualism and its possible limits in their clients. To avoid misunderstanding, they did not hesitate to translate certain Greek technical terms, glossing them with the appropriate Coptic word, intro-


cubbyhole under the staircase, or khrere"; cf. Sijpesteijn 1992, 242; Torallas Tovar 2004, 170).

\section{Deficient Literacy}

Coptophone writers frequently betray themselves by their handwriting (e.g., in unligatured uncials), their Copticization of personal or Egyptian geographical names, introducing Coptic letters, or replacing Greek terminations (-os by $-\epsilon$, for example), their untimely insertions of Coptic words, and their phonetic mistakes such as the confusion of consonants (e.g., mixing voiceless and voiced consonants, replacing $\rho$ with $\lambda$ in the Fayyum) or of vowels (e.g., ignorance of Greek quantities, variation in the use of vowels because of the tendency of the Coptic system accent to change vowel qualities). ${ }^{33}$ Sometimes deficient syntax is the clue. Cases of Copticisms are more doubtful or difficult to distinguish (see, e.g. P.Ross.Georg. IV, appendix, p. 99, a letter full of Copticisms, or, in literature, Torallas Tovar 2004, 172).

\section{Illiteracy}

As in the Roman period, those illiterate in Greek could avail themselves of various solutions: asking a literate person to write a letter for them or, in the case of legal documents, to subscribe on their behalf with the usual formula: "I, so and so, wrote on his behalf because he does not know how to write."
Translation must have played a more important role than our documentation allows us to see. In contracts where the main party did not know Greek, the text was translated for him by the notary. We know only two examples in which such a phenomenon is expressly signaled:

- P.Münch. I 13.71 (Syene, 594), a sale contract entered into by two women with Egyptian names (Tsônê and Tseure), who declare at the end that they agree with the text "after it had been read to us and translated into Egyptian."

- P.Lond. I 77.69 (p. 231) (Hermonthis, ca. 60o), the will of Bishop Abraham, mentioned earlier, which ends with the statement that "everything was translated into Egyptian for me by the notary named below."

It is obvious that in most cases this formula was omitted even though translation had occurred. That went without saying.

Public offices also needed translation in order to publicize certain texts. Thus, an order by the duke of the Thebaid on payments to officials had to be "translated into the vernacular language and posted" (P.Cair.Masp. I 67031.16, sixth century). Here we see the administration taking account of the linguistic limitations of its population, something that contradicts the popular image of a haughty imperial power that despised the vernacular languages.

One methodological conclusion is unavoidable: Egypt, because of the quantity of its preserved written documentation, is an ideal setting in which to observe the phenomenon of multilingualism. This cannot be understood without taking into account the totality of the written sources in the various languages, each of which illumines a different and complementary facet of its history. The era of a Hellenocentric papyrology has passed, and the papyrologist or historian of Egypt today must dismantle the barriers between the various bodies of material in order to let them converse with one another.

\section{NOTES}

1. Diglossia means here the coexistence in a single society of two languages distinguished by their function - a phenomenon not identical to bilingualism. For the application and development of this concept see Adams (2003, 537-541).

2. For the dates see Altheim-Stiehl (1991, 1992a, 1992b).

3. The few papyri with both Greek and Pehlevi are actually reuses of Greek documents by the Persians.

4. For the first, cf. CII, P. 149; for the second, CII, P. 140 (with commentary on pp. 23-24). 
5. The Latin papyri have been collected in the following corpora: C.Pap.Lat: gathered documents and literary texts; C.Epist.Lat. is devoted to letters; finally and most important, Ch.L.A. assembles texts that contain Latin, whether puhlished or not, by the country of collection. The numbers that I give here are hased on the Heidelberger Gesamt verzeichnis det griechischen Papyrusurkunden Ägyptens (http://www.rzuser.uni-heidelberg. de/ gvo/gvz.html): They exclude about 430 texts that are undated or of non-Egyptian provenance (like the papyri of Dura on the Middle Euphrates or the ostraca of Bu Njem in Libya).

6. See Fournet (2003a, 431-446).

7. P.Abinn., SBXIV 11380, and perhaps P.Gen. I 80, SB VI 9605, X 10755, and XX 14954

8. Here Adams modifies the opposition developed by C. A. Ferguson in his definition of diglossia between low language and high language (Adams 2003, 538). Adams rightly prefers to see Latin as a "super-high" language and Greek as a high language.

9. SB XX 14726 (Arsinoite, 399), letter of the pretorian prefect to the governor of Arcadia (accompanying an order in Greek).

10. For example, PSI I 112 (316), P.Lips. I 44 (324-337), Ch.L.A. XVII 657 (436-450), SB $\mathrm{XX} 14606(425-450)$, with the end of a rescript that concludes with the autograph signature of Theodosius II.

11. A list of these texts is given in P.Oxy. LI, pp. 47-48 and Thomas $(1998,132-134)$. See also Rochette (1997, 119-120).

12. For example, in Ch.L.A. XVIII 660 , a list of soldiers of the ala III Assuriorum (326 or 329), we read in II 2: prigceps I turm $\eta$ s in place of princeps I turmae (cf. Adams 2003 . 618-621).

13. The graph is based on the Leuven Database of Ancient Books, http://dab.arts. kuleuven.be/ldab_text.php.

14. Byzantine notarial signatures are collected hy Diethart and Worp (1986). Kramer $(1984,1382)$ studies those in Latin letters briefly.

15. Collected in C.Gloss.Biling.

16. The volumes of Coptic documentary papyri are included in the Checklist (littp:l) scriptorium.lib.duke.edu/papyrus/texts/clist.html). There is also now the Banque de dont nées des textes coptes documentaires by Alain Delattre (http://dev.ulb.ac.be/philo/bad/copte/ base.php?page $=$ accueil.php). The Leuven Database of Ancient Books now includes Coptic literary papyri. For Coptic literature see Krause (1980) and Orlandi (1998). An electronic corpus of Coptic manuscripts is being developed under the direction of T. Orlandi (http rmcisadu.let.tuniromax.it $/ \sim \mathrm{cmcl} /$ ).

17. Greek words in Coptic documentary texts have been collected by Forrster (2002:914 pages).

18. In parentheses I give the abbreviations used in the dictionary of Crum (1939).

19. The ecumenical council of Chalcedon (451), by condemning the theological positions of Dioscoros, the bishop of Alexandria, created a schism between partisans of the Chalcedonian creed (supported hy the emperor) and those of Dioscoros (anti-Chalcedonians or monophysites).

20. The graphs are based, for the Greek documents, on Habermann (1998, 147) and, for the Coptic, on the Banque de données des textes coptes documentaires of Alain Delattre (see note 16).

21. The data in this graph should be considered with some reservation: Many papyri have only approximate dates. Thus, I have interpreted "III/IV" as "third or fourth" rather than "end of the third, beginning of the fourth." Moreover, many documents were published with no title or only a vague one.

22. Greek texts: P.Lond. VI 1913-1919; Coptic: P.Lond. VI 1920-1922, and Crum (1927).

23. Greek texts: P.Neph. 1-14, 17-42; Coptic: P.Neph. 15, 16.

24. Greek texts: P.Herm. 7-10, 17, P.Amh. II 145 (with signature in Coptic), P.Lond. III 981 (p. 241); SB XVIII 13612; Coptic texts: P.Ryl.Copt. 268-274, 276, and perhaps 275, 292, 301, 310-314, 396, P.Lond.Copt. I 1123. On this archive see Zuckerman (1995) and Clackson (2004, 24-25).

25. Palladius, Historia Lausiaca, 35, and Historia monachorum in Aegypto, 1.

26. Greek texts: P.Kell. I (documents and subliterary texts), III (Isocrates), IV (account book), O.Kellis (documents), and some literary texts in vol. II (G. 91-94); Coptic texts: $P$. Keill. II and VI (literary), V (documents). It should be noted that some of these texts,

athough found at Kellis, were sent from the Nile valley.

27. Greek texts: principally P.Cair.Masp. I-III, P.Flor. I 93, III 279-298, 342, P.Lond. V 1660-1718, Coptic texts: see a provisional list in Fournet 2003b, 170-175. For a complete list of the texts composing this archive and the other archives related to it, see Fournet (2008, 807-343). On the Coptic archive of Dioscoros, see Clackson (2004, 25-28).

28. P.Cair.Masp. III 67353 recto, copy of the document edited by MacCoull (1985), the first dated Coptic text (569), and P.Lond. V 1709 . Abous these texts (and another still unpublished) see Fournet (forthcoming). On the arbitrations, cf. P.Mich.Aphrod.

29. This archive also includes an older group (493-557/558), which is indirectly connected to it. Greek texts: P.Lond. V 1719-1737, 1846-1850, 1852-1859, 1861, P.Münch. I 1-16; Coptic texts: O.CrumST 439, SB Kopt. III 1293, 1394, 1395, 1666, and perhaps P.Lond.Copt. I 446 and O.CrumST 116, 423. On the Coptic side of this archive, see Clackson (2004, 28-29).

30. Coptic texts: Krause (1956); Greek text: P.Lond. I 77 (p. 231).

31. Greek texts: P.Par. 20; 21; 21bis; 21ter, SB I 4503-4505; 5285-5287; Coptic texts: CPR V 23 perhaps 83 .

32. For the dates of P.Vat.Copt., still unpublished except the first one (Förster and Mithof 2004), see Bagnall and Worp (2004). On some of these texts, see MacCoull (1997). B.CrumST 48 and O.CrumVC 5 can be dated owing to their link with SB I 5112.

33. See Gignac $(1976,332-333)$

\section{BIBLIOGRAPHY}

CI - D. Weber, Ostraca, Papyri, und Pergamente: Textband. Corpus Inscriptionum Iranicarum. Part 3. Pahlavi Inscriptions. Volume 4. Ostraca and Papyri. Texts I. London 1992: D. Weber, Berliner Papyri, Pergamente und Leinenfragmente in mittelpersischer Sprache. Corpus Inscriptionum Iranicarum. Part 3. Pahlavi Inscriptions. Volume 4, Ostraca, and vol. 5, Papyri. London 2003 (photos in J. de Menasce, Ostraca and Papyri. Corpus Inscriptionum Iranicarum. Part 3. Pahlavi Inscriptions. Volume 4-5. Ostraca and Papyri. Portfolio I. London 1957).

Mertens-Pack ${ }^{3}+$ number = Catalogue des papyrus littéraires grecs et latins. http:// promethee.philo.ulg.ac.be/cedopal/index.htm. 
1993. "Linscription grecque de l'église Al-Mu'allaqa." Bulletin de l'Institut français d'Archéologie Orientale 93: 237-244.

Adams, J. N. 2003. Bilingualism and the Latin Language. Cambridge: Cambridge University Press.

Agosti, G. 2002. "Il poemetti del Codice Bodmer e il loro ruolo nella storia della poesia tardoantica." In Le Codex des Visions, ed. A. Hurst and J. Rudhardt, 73-114. Geneva Librairie Droz.

Altheim-Stiehl, R. 1991. "Wurde Alexandreia im Juni 619 n. Chr. durch die Perser erobert? Bemerkungen zur zeitlichen Bestimmung der sāsänidischen Besetzung Ägyptens unter Chosrau II. Parwēz." Tyche 6: 3-16.

1992a. "The Sasanians in Egypt: Some Evidence of Historical Interest": BSAC 31: 87-96: ـــ. 1992b. "Zur zeitlichen Bestimmung der sāsänidischen Eroberung Ägyptens: Ein neuer terminus ante quem für Oxyrhynchos ist nachzutragen." In MOY $21 K O 2$

ANHP: Festschrift für Max Wegner zum 9o. Geburtstag, ed. O. Brehm and S. Klie 5-8: Antiquitas, Reihe 3. Bonn: Habelt.

Bagnall, R. S. 1993. Egypt in Late Antiquity. Princeton: Princeton University Press.

- 2005. "Linguistic Change and Religious Change: Thinking about the Temples of the Fayoum in the Roman Period." In Christianity and Monasticism in the Fayoum Oass: ed. G. Gabra, 11-19. Cairo: American University in Cairo Press.

- and K. A. Worp. 2004. "Dating the Coptic Legal Document from Aphrodite" ZPE 148: $247-252$.

Butler, A. J., and P. M. Fraser. 1978. The Arab Conquest of Egypt and the Last Thirty Years of the Roman Dominion, 2d ed. Oxford: Clarendon.

Cavenaile, R. 1987. "Le latin dans les milieux chrétiens d'Égypte." Miscel-lánia Papirologica Ramon Roca-Puig, 103-110. Barcelona.

Clackson, S. I. 2004. "Papyrology and the Utilization of Coptic Sources." In Papyrology an the History of Early Islamic Egypt, ed. P. M. Sijpesteijn and L. Sundelin, 21-44. Leiden Brill.

Cribiore, R. 1996. Writing, Teachers, and Students in Graeco-Roman Egypt. American Studies in Papyrology 36. Atlanta: Scholars Press.

- 1999. "Greek and Coptic Education in Late Antique Egypt." In Ägypten und Nibien in spätantiker und christlicher Zeit, ed. S. Emmel, M. Krause, S. G. Richter, and S. Sehaten. Vol. 2, 279-286. Wiesbaden: Reichert.

Crum, W. E. 1927. "Some Further Melitian Documents." JEA 13: 21-25.

- 1939. A Coptic Dictionary. Oxford: Clarendon.

Daris, S. 1991. Il lessico latino nel greco d'Egitto, $2 \mathrm{~d}$ ed. Estudis de Papirologia 1 Filologia bíblica 2. Barcelona: Institut de Teologia Fonamental.

Diethart, J. M., and K. A. Worp. 1986. Notarsunterschriften im byzantinischen Agypten, MPER N.S. 16. Vienna: Hollinek.

Förster, H. 2002. Wöterbuch der griechischen Worter in den koptischen dokumentarischen Texten, TU 148. Berlin: De Gruyter.

Förster, H., and F. Mitthof. 2004. "Ein koptischer Kaufvertrag über Anteile an einem Wagen. Edition von P.Vat.Copt. Doresse 1," Aegyptus 84: 217-242.

Foss, C. 2002. "The Sellarioi and the Other Officers of Persian Egypt." ZPE 138: 169-172.

Fournet, J.-L. 1992. "Une éthopée de Cain dans le Codex des Visions de la Fondation Bodmer." ZPE 92: 253-256.

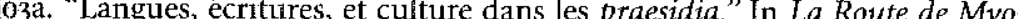

Hormos: L'armée dans le désert Oriental d'Égypte, ed. H. Cuvigny, 427-500. Fouilles de LIFAO 48. Cairo: Institut français d'archéologie orientale.

2003b. "Une lettre copte d'Aphrodité? (Révision de SB Kopt. I 290)." In Études coptes VII, ed. C. Cannuyer, 163-175. Lille-Paris: Association francophone de coptologie.

2008. "Liste des papyrus édités de l'Aphrodité byzantine." In Les archives de Dioscore d'Aphrodité cent ans après leur découverte. Histoire et culture dans l'Égypte byzantine, ed. J.-L. Fournet, 307-343. Études d'archéologie et d'histoire ancienne. Paris: de Boccard. . forthcoming. "Sur les premiers documents juridiques coptes." In Etudes coptes XI, Treizième journée d'études (Marseille, 7-9 juin 2007), ed. A. Boud'hors and C. Louis. Cahiers de la Bibliothèque copte 17. Paris: de Boccard.

Cascou, I 2000. "Fragment d'un codex juridique du Bas-Empire (P.Strasb. L 9)." In La codification des lois dans l'Antiquité, ed. E. Lévy, 285-291. Travaux du CERPEOGA 16. Paris: de Boccard.

Ghiretti, E. 1996. "Note sul bilinguismo greco-latino dell'Egitto romano." Aevum 9: $275-298$.

Gignac, F. T. 1976. A Grammar of the Greek Papyri of the Roman and Byzantine Periods. Vol. 1, Phonology Milan: Istituto editoriale Cisalpino-La Goliardica.

Grohmann, A. 1952. From the World of Arabic Papyri. Cairo: Al-Maaref Press.

Habermann, W. 1998. "Zur chronologischen Verteilung der papyrologischen Zeugnisse." ZPE $122.144-160$

Hityse, Ph, 1995. "Die mittelpersische Papyrologie: Fortschritte und Ziel einer jungen Wissenschaft." Indo-Iranian Journal 38: 357-367.

Kramer, J. 1984. "Testi greci scritti nell'alfabeto latino e testi latini scritti nell' alfabeto greco: un caso di bilinguismo imperfetto." In Atti del XVII Congresso Internazionale di Papirologia, vol. 3, 1377-1384. Naples: Centro internazionale per lo studio dei papiri ercolanesi.

Krause, M. 1956. "Apa Abraham von Hermonthis: Ein oberägyptischer Bischof um 600." Ph.D. Diss., University of Berlin.

-1980. "Koptische Literatur." In Lexikon der Ägyptologie, vol. 3, 694-728. Wiesbaden: Harrassowitz.

Teris, N. 1993. "The Demise of the Demotic Document: When and Why." JEA 79: 276-281.

MacCoull, L. S. B. 1985. "A Coptic Cession of Land by Dioscorus of Aphrodito: Alexandria meets Cairo." In Acts of the Second International Congress of Coptic Study, ed. T. Orlandi and F. Wisse, vol. 7, 159-166. Rome: CIM (=L. S. B. MacCoull, Coptic Perspectives on Late Antiquity [Aldershot: Variorum, 1993], no. VII).

1986. "Coptic Egypt during the Persian Occupation: The Papyrological Evidence." Studi Classici e Orientali 36: 307-313 (=L. S. B. MacCoull, Coptic Perspectives on Late Antipuity [Aldershot: Variorum, 1993], no. XII).

1991 "A Coptic Monastic Letter to Dioscorus of Aphrodito." Enchoria 18: 23-25.

1992. "More Missing Pieces of the Dioscorus Archive." In Actes du IVe Congrès copte, ed. M. Rassart-Debergh and J. Ries, 104-112. Publications de l'Institut orientaliste de Louvain 41. Louvain-la-Neuve: Université catholique de Louvain, Institut orientaliste. 1993. "The Apa Apollos Monastery of Pharoou (Aphrodito) and Its Papyrus Archive." Le Muséon 106: 21-64. 
- 1995. "Further Notes on Interrelated Greek and Coptic Documents of the Sixth and Seventh Centuries." Cd'É 70: $341-353$.

—_. 1997. "Dated and Datable Coptic Documentary Hands before A.D. 700? Le Muséo 110: 349-366.

Mertens, P. 1987. "Les papyrus littéraires latins d'auteurs classiques durant les deux der nières décennies." Miscel.lània Papirològica Ramon Roca-Puig, 189-204 Barcelona.

Moscadi, A. 1970. "Le lettere dell' archivio di Teofane." Aegyptus 50: 88-154.

Orlandi, T. 1998. "Koptische Literatur." In Ägypten in spätantik-christlicher Zeit. Einfihrums in die koptische Kultur, ed. M. Krause, 117-147. Wiesbaden: Reichert.

Osing, J. 1998. Hieratische Papyri aus Tebtynis, vol. 1. Copenhagen: Carsten Niebuhr Institute.

Quagebeur, J. 1982. "De la préhistoire de l'écriture copte." Orientalia Lovaniensia Períodica 13: 125-136.

Richter, T. S. 2002. Rechtsemantik und forensische Rhetorik: Untersuchung zu Wortschatz, Stit und Grammatik der Sprache koptischer Rechtsurkunden. Kanobos 3. Leipzig. Wodtke und Stegbauer. Reprinted with a new introduction, Wiesbaden: Harrassowitz, 2008.

Rochette, B. 1990. "Les traductions grecques de l'Énéide sur papyrus: Une contribution $\mathrm{d}$ ' l'étude du bilinguisme gréco-romain au Bas-Empire." Etudes Classiques 58: 333-346.

—. 1996. "Papyrologica bilinguia Graeco-latina." Aegyptus 76: 57-79.

-1997. Le latin dans le monde grec: Recherches sur la diffusion de la lanoue et des lette latines dans les provinces hellénophones de l'Empire romain. Collection Latomus. 233. Brussels: Latomus.

— 1999. "Écrire en deux langues: Remarques sur le mixage des écritures grecque et latine d'après les papyrus littéraires bilingues d'auteurs classiques." Scriptoriın 53: 325-334. Sänger, P. 2008. "Saralaneozan und die Verwaltung Ägyptens unter den Sassaniden." 2PE 164: 191-208.

Schubert, P. 2002. "Contribution à une mise en contexte du Codex des Visions." In Le Codex des Visions, ed. A. Hurst and J. Rudhardt, 19-25. Geneva: Librairie Droz.

Sijpesteijn, P. J. 1992. "The Meanings of "̈rot in the Papyri." ZPE 90: 241-250.

Thomas, J. D. 1998. "P.Ryl. IV 654: the Latin Heading," Cd'É 73: 125-134.

Torallas Tovar, S. 2004. "Egyptian Lexical Interference in the Greek of Byzantine and Early Islamic Egypt." In Papyrology and the History of Early Islamic Egypt, ed. P. M. Sipestein and L. Sundelin, 163-198. Leiden: Brill.

Turner, E. G. 1961. "Latin versus Greek as a Universal Language: The Attitude of Diocletian? In Language and Society: Essays Presented to Arthur M. Jensen on His Seventieth Birthday, 165-168. Copenhagen: Berlingske.

Van Minnen, P. 1994. "The Roots of Egyptian Christianity." APF $40: 71-85$.

Weber, D. 1991. "Ein bisher unbekannter Titel aus spätsassanidischer Zeit?' In Coroll Iranica: Papers in Honour of Prof. Dr. David Neil MacKenzie on the Occasion of His 6 st th Birthday, ed. R. E. Emmerick and D. Weber, 228-236. New York: P. Lang.

- 1992a. "Pahlavi Papyri Revisited." In Proceedings of the XIXth International Congress of Papyrology, vol. 2, 493-508. Cairo: Ain Shams University.

- $1992 \mathrm{~b}$ and 2003. cf. CII

Wipszycka, E. 1992. "Le nationalisme a-t-il existé dans l'Égypte byzantine?". Journal of Juristic Papyrology 22: 83-128 (=E. Wipszycka, Études sur le christianisme dans l'Ervpte de l'Antiquité tardive. Studia Ephemeridis Augustinianum 52. Rome: Studia Ephemeridis Augustinianum, 1996, I.1).
Worp, K. A. 1984. "Studien zu spätgriechischen, koptischen und arabischen Papyri" Bulletin de la Société d'Archéologie Copte 26: 99-107.

Wouters, A. 1988. The Chester Beatty Codex Ac. 1499: A Graeco-Latin Lexicon on the Pauline Epistles and a Greek Grammar. Leuven-Paris: Peeters.

Zuckerman, C. 1995. "The Hapless Recruit Psois and the Mighty Anchorite, Apa John." BASP 32: 183-194. 